\title{
Association of Genetic Polymorphism of IL-2 Receptor Subunit and Tuberculosis Case
}

\author{
Sang-In Lee, Hyun-Seok Jin and Sangjung Park ${ }^{\dagger}$ \\ Department of Biomedical Laboratory Science, College of Life and Health Sciences, \\ Hoseo University, Asan, Chungnam 31499, Korea
}

\begin{abstract}
Tuberculosis (TB) is infectious disease caused by Mycobacterium tuberculosis (MTB) infection. It is known that not only the property of microorganism but also the genetic susceptibility of infected patients is controlled. Interleukin 2 (IL-2) is a cytokine belonging to type $1 \mathrm{~T}$ helper (Th1) activity. In addition, IL-2, when infected with MTB, binds IL-2 receptor and promotes $\mathrm{T}$ cell replication and is involved in granuloma formation. The aim of this study was to investigate the genetic polymorphisms of the IL-2 receptor gene in tuberculosis patients and normal individuals. We analyzed 22 SNPs in three genes using the genotype data of 443 tuberculosis cases and 3,228 healthy controls from the Korea Association Resource for their correlation with tuberculosis case. IL2RA,IL2RB, and IL2RG genes were genotyped of 16, 4, and 2 SNPs, respectively. Among three genes, only $I L 2 R A$ gene polymorphisms showed statistically significant association with tuberculosis case. 6 SNPs with high significance were identified in the IL2RA gene. In addition, the linkage disequilibrium (LD) structure of $I L 2 R A$ gene was confirmed. SNP imputation of $I L 2 R A$ gene was performed, it was confirmed that more SNPs were significant between case and control. If we look at the results of IL2RA gene analysis above, we can see that genetic polymorphism in the gene expressing IL-2R $\alpha$ will regulate the expression level of IL-2R $\alpha$, and the change in the immune system involved in IL-2R $\alpha$. In this study, genetic polymorphism that may affect host immunity suggests that susceptibility to tuberculosis may be controlled.
\end{abstract}

Key Words: IL2RA, Tuberculosis, Genetic association, Mycobacterium tuberculosis, SNP, Polymorphism

\section{서 론}

결핵은 결핵균 감염에 의해 발병하는 질병으로 전 세계 $1 / 3$ 이 감염되어 있고 국내에서 아직까지 높은 발병률과 사망률을 보이고 있는 질병이다(Corbett et al., 2003). 결핵 균에 감염된 사람 중 약 $10 \%$ 는 결핵으로 발병한다. 결핵 발병은 결핵균이 가지고 있는 균의 특성 뿐만 아니라 결 핵균 감염 환자의 유전적 감수성이 조절한다고 알려져 있다(Comstock, 1978). 현재 결핵 발병과 유전적 감수성에
대한 상관성을 보는 연구가 많이 진행되고 있다.

Interleukin 2 (IL-2)는 CD4+ helper $\mathrm{T}$ cell 중 type $1 \mathrm{~T}$ helper (Th1) activity가 분비하는 cytokine으로 결핵균에 대 한 면역반응에 필요하다. 그리고 $\mathrm{Th} 1$ 그룹 cytokine들의 상호작용에 관여하여 $\mathrm{T}$ cell의 면역반응에 중요한 역할 을 한다고 알려져 있다(Caccamo et al., 2010). 또한 IL-2는 chain $\alpha, \beta, \gamma$ 로 이루어진 receptor와 결합하여 세포 내부로 생화학적 신호를 전달한다(Gaffen and Liu, 2004).

IL-2가 T cell에서 Major histocompatibility complex (MHC)peptide 복합체를 인식한 후 $\mathrm{T}$ cell의 항원 수용체인 T-cell

* Received: May 3, 2018 / Accepted: May 17, 2018

${ }^{\dagger}$ Corresponding author: Sangjung Park. Department of Biomedical Laboratory Science, College of Life and Health Sciences, Hoseo University, Asan, Chungnam 31499, Korea.

Tel: +82-41-540-9967, Fax:+82-41-540-9997, e-mail: sangjung@hoseo.edu

(C) The Korean Society for Biomedical Laboratory Sciences. All rights reserved.

(9) This is an Open Access article distributed under the terms of the Creative Commons Attribution Non-Commercial License (http://creativecommons.org/licenses/by-nc/3.0/) which permits unrestricted non-commercial use, distribution, and reproduction in any medium, provided the original work is properly cited. 
receptor를 통해 세포 내부로 신호를 전달한다. 이렇게 세 포 내부로 전달된 신호는 세포 변화를 일으켜 초기 $\mathrm{T}$ cell 이 effector T cell과 memory T cell로 분화하도록 촉진한다. 또한 세균이나 바이러스에 감염된 세포가 정상 $\mathrm{T}$ cell을 공격하는 것을 억제한다(Liao et al., 2011). 결핵균에 감염되 면 T cell이 활성화되어 IL-2를 분비하고 IL-2 receptor를 세 포 표면에 발현한다. 이때 $\mathrm{IL}-2$ 는 $\mathrm{T}$ cell의 증식을 촉진하 고 육아종 형성에 관여하며 결핵 감염에 대한 통제 및 면 역에 핵심적인 역할을 수행한다(Kaufmann, 2001; Wang et al., 2012; Sharma et al., 2014). IL-2 receptor 중 $\alpha$ chain은 $\beta, \gamma$ chain과는 다르게 soluble한 형태로 혈중으로 유리되고 혈 중 $\mathrm{IL}-2$ receptor $\alpha(\mathrm{IL}-2 \mathrm{R} \alpha)$ 의 농도는 유전자의 발현 정도 에 따라 달라진다. 따라서 혈중 IL-2Ra의 농도는 T cell 활성의 지표가 되기도 한다(Rubin et al., 1985; Wang et al., 2012). 또한 결핵균이 잠복 감염된 환자에서 IL-2와 IFN- $\gamma$ 를 모두 발현하는 $\mathrm{T}$ cell의 비율이 현성 감염 환자에 비하 여 높은 것으로 나타났다는 결과를 보고한 연구도 진행되 었다(Casey et al., 2010; Sester et al., 2011).

따라서 본 연구에서는 한국인 유전체 역학 조사 사업의 일환으로 구성되어 있는 코호트 자료를 활용하여 결핵 환 자와 정상인 간 IL-2 receptor 유전자의 유전적 다형성이 결핵 발병에 영향을 주었는지 확인하고자 유전적 변이에 대한 상관성 분석 연구를 시행하였다.

\section{재료 및 방법}

\section{연구대상자}

본 연구를 위한 한국인 연구대상자는 한국인 유전체 역 학 조사 사업(Korean Genome and Epidemiology Study; KoGES)의 일환인 Korean Association Resource (KARE)를 기반으로 하였다(Cho et al., 2009). 이때 사용한 자료는 질 병관리본부 인체자원은행에서 분양을 받아 사용하였다 (17070301-01-01). 연구에서 사용한 연구대상자의 선별은 이전 연구와 동일하게 설정하였다(Jin and Park, 2017). 요 약하면 환자군으로는 과거에 결핵진단을 받은 적이 있는 443 명을 선정하였고 건강 대조군은 특별한 질환이 없는 3,228 명을 선정하였다. 결핵 환자군과 건강 대조군의 평균 나이는 각각 51.0세와 51.6세로 유사하였다. 본 연구에 활 용한 유전 정보는 질병관리본부 $(\mathrm{KNIH})$ 와 호서대학교에서 연구윤리 승인을 받은 후 분석을 수행하였다(1041231170418-HR-056-02).

\section{유전형 분석과 Single Nucleotide Polymorphism (SNP) 선별}

본 연구에서는 KARE 유전형 자료를 기반으로 SNP 을 선별하였다. DNA 시료는 연구 참여자의 말초혈액에 서 분리 추출하였고, 유전형 판독을 위해서는 Affymetrix Genome-Wide Human SNP array 5.0 (Affymetrix, Inc., Santa Clara, CA, USA)를 사용하였다. 유전형 판독 정확도가 $98 \%$ 이하이거나, $4 \%$ 이상의 높은 missing genotype call rate을 보이거나, $30 \%$ 초과의 heterozygosity를 가지거나, 성별 불 일치가 존재하는 대상자들은 제외되었다. 본 연구에서 분 석한 $I L 2 R A, I L 2 R B, I L 2 R G$ 유전자 영역은 전사체 양 말 단에서 $5 \mathrm{~kb}$ 씩 확장하여 이 범위에 존재하는 각각 16 개, 4 개, 2 개의 SNP들을 대상으로 하였다. 이 SNP들의 염색 체 상의 위치는 UCSC Genome Browser on Human Mar. 2006 (NCBI36/hg18)를 기준으로 하였다. 또한, 실제 실험적으로 $\mathrm{SNP}$ 의 유전형을 확인한 것 이외에도 IL2RA 유전자 영역 에서는 MACH 1.0.16 (Li et al., 2010)를 사용하여 추가적으 로 37 개의 imputation SNP을 발굴하여 분석에 사용하였 다. Imputation은 HapMap database (release 24) (International HapMap Consortium 2003)에서 중국인(Han Chinese form Beijing)과 일본인(Japanese in Tokyo)의 것을 참고로 진행하 였다. Imputed SNP들 중에서 Minor Allele Frequency (MAF) 가 $1 \%$ 미만이거나 상관계수 $\left(r^{2}\right)$ 가 0.5 미만인 것은 분석 에서 제외하였다.

\section{상관성 분석과 통계 분석}

대부분의 통계 분석에는 PLINK version 1.07 (http:// pngu.mgh.harvard.edu/ purcell/plink)과 PASW Statistics version 18.0 (SPSS Inc. Chicago, IL, USA)을 사용하였다. 결핵 환자 군과 건강 대조군에 대한 유전적 변이의 상관성 분석은 Logistic 회귀 분석을 사용하였으며 additive genetic model 을 기반으로 하였다. 분석 값에 대한 유의 수준은 0.05 이하를 기준으로 하였다. KARE 유전형 정보를 바탕으로 Haploview version 4.2 (Whitehead Institute for Biomedical Research, Cambridge, MA, USA) 프로그램을 사용하여 연관 불균형(linkage disequilibrium) 블록 구조를 확인하였다.

\section{결 과}

$I L 2 R A, I L 2 R B, I L 2 R G$ 유전자 영역의 SNP 선별과 상관 성 분석 결과

IL-2 receptor 유전자들은 UCSC Genome Browser on 
Human Mar. 2006 (NCBI36/hg18)를 기준으로 각각 염색체 에서 유전자의 영역을 설정(전사체 기준으로 하여 양방 향으로 $5 \mathrm{~kb}$ 씩 영역 확장)한 후 $\mathrm{KARE}$ 유전형 자료에서 $\mathrm{SNP}$ 을 확인하였다. 그 결과 IL $2 R A$ 는 10 번 염색체에서 16 개의 $\mathrm{SNP}$ 이 확인되었다. 마찬가지로 $I L 2 R B$ 는 22 번 염색 체에서 4 개의 $\mathrm{SNP}$ 이 $I L 2 R G$ 는 $\mathrm{X}$ 염색체에서 2 개의 $\mathrm{SNP}$ 을 확인할 수 있었다. 선별된 IL-2 receptor 유전자의 SNP 을 대상으로 결핵 환자군과 건강 대조군에 대한 Logistic 회귀 분석을 시행한 결과 $I L 2 R A$ 유전자의 16 개의 $\mathrm{SNP}$ 중 6 개의 $\mathrm{SNP}$ 에서 통계적으로 유의한 상관관계 $(P<0.05)$ 를 확인할 수 있었다. 그러나 IL $2 R B$ 유전자에서는 분석 결과 통계적으로 유의한 $\mathrm{SNP}$ 이 존재하지 않았으며, IL2RG 유 전자는 $\mathrm{X}$ 염색체의 특이성으로 분석 결과에 의미를 부여
하기가 어려웠다(Table 1).

$I L 2 R A$ 유전자의 $\mathrm{SNP}$ 중 가장 높은 유의 수준 $(P=1.10$ $\left.\times 10^{-3}\right)$ 을 보이는 rs7072398은 상대적 위험도 $(\mathrm{OR})$ 는 0.78 으로 나타났고 신뢰구간 $(95 \% \mathrm{CI})$ 은 $0.68 \sim 0.91$ 으로 나타났 다. rs7072398의 minor allele는 $\mathrm{T}$, major allele는 $\mathrm{C}$ 이다. $\mathrm{MAF}$ 를 살펴보면 결핵 환자군은 $36.4 \%$ 이고, 건강 대조군 은 $42.2 \%$ 로 약 $6 \%$ 의 빈도 차이가 있어서 $\mathrm{T}$ 염기를 보유 할 경우에 결핵 발생을 감소시키는 방향으로 상관성이 있는 것을 알 수 있었다. 그러나 rs2256774는 상대적 위험 도가 1.3으로 확인되어 minor allele를 보유하고 있을수록 결핵 발생을 증가시키는 방향으로의 상관성이 있다는 것 을 알 수 있었다. 유의성이 높은 6개의 SNP 중 rs2256774 를 제외한 5 개의 $\mathrm{SNP}$ 은 상대적 위험도가 낮게 확인되었

Table 1. Results of the case-control association analysis between SNPs in the IL2RA, IL2RB, IL2RG genes and tuberculosis in the KARE subjects

\begin{tabular}{|c|c|c|c|c|c|c|c|c|c|c|}
\hline \multirow[b]{2}{*}{ Gene } & \multirow[b]{2}{*}{ No. } & \multirow[b]{2}{*}{ SNP } & \multirow[b]{2}{*}{$\mathrm{BP}$} & \multirow[b]{2}{*}{ Function } & \multirow[b]{2}{*}{ A1 } & \multirow[b]{2}{*}{ A2 } & \multicolumn{2}{|c|}{ MAF } & \multirow[b]{2}{*}{ OR $(95 \% \mathrm{CI})$} & \multirow{2}{*}{$\begin{array}{l}\text { Additive } \\
P \text { value }\end{array}$} \\
\hline & & & & & & & $\begin{array}{c}\text { Cases } \\
(\mathrm{n}=443)\end{array}$ & $\begin{array}{c}\text { Controls } \\
(\mathrm{n}=3,228)\end{array}$ & & \\
\hline \multirow{16}{*}{$I L 2 R A$} & 1 & rs 11596355 & 6104187 & Intronic & G & A & 0.012 & 0.015 & $0.90(0.48 \sim 1.68)$ & 0.730 \\
\hline & 2 & rs2025345 & 6107694 & Intronic & $\mathrm{C}$ & $\mathrm{T}$ & 0.377 & 0.431 & $0.79(0.68 \sim 0.92)$ & $\underline{2.77 E-03}$ \\
\hline & 3 & rs 12722527 & 6117334 & Intronic & $\mathrm{T}$ & $\mathrm{C}$ & 0.173 & 0.167 & $1.05(0.87 \sim 1.27)$ & 0.624 \\
\hline & 4 & rs 11256433 & 6117851 & Intronic & $\mathrm{C}$ & A & 0.285 & 0.260 & $1.13(0.96 \sim 1.32)$ & 0.137 \\
\hline & 5 & rs 11256448 & 6119485 & Intronic & G & A & 0.303 & 0.286 & $1.08(0.92 \sim 1.26)$ & 0.343 \\
\hline & 6 & rs7072398 & 6119852 & Intronic & $\mathrm{T}$ & $\mathrm{C}$ & 0.364 & 0.422 & $0.78(0.68 \sim 0.91)$ & $\underline{1.10 \mathrm{E}-03}$ \\
\hline & 7 & rs4749926 & 6125318 & Intronic & A & G & 0.357 & 0.408 & $0.80(0.69 \sim 0.92)$ & $\underline{2.56 \mathrm{E}-03}$ \\
\hline & 8 & rs 10905656 & 6126099 & Intronic & $\mathrm{C}$ & A & 0.392 & 0.359 & $1.15(0.99 \sim 1.33)$ & 0.066 \\
\hline & 9 & rs942201 & 6126298 & Intronic & $\mathrm{A}$ & $\mathrm{C}$ & 0.276 & 0.255 & $1.10(0.94 \sim 1.29)$ & 0.233 \\
\hline & 10 & rs791587 & 6128705 & Intronic & A & G & 0.270 & 0.322 & $0.78(0.66 \sim 0.91)$ & $\underline{1.65 E-03}$ \\
\hline & 11 & rs 10905668 & 6132061 & Intronic & A & G & 0.373 & 0.345 & $1.12(0.97 \sim 1.29)$ & 0.134 \\
\hline & 12 & rs 10905669 & 6132099 & Intronic & A & G & 0.374 & 0.345 & $1.12(0.97 \sim 1.30)$ & 0.118 \\
\hline & 13 & rs 2256774 & 6137171 & Intronic & $\mathrm{C}$ & $\mathrm{T}$ & 0.101 & 0.079 & $1.30(1.03 \sim 1.65)$ & $\underline{3.00 \mathrm{E}-02}$ \\
\hline & 14 & rs2104286 & 6139051 & Intronic & $\mathrm{C}$ & $\mathrm{T}$ & 0.105 & 0.100 & $1.05(0.84 \sim 1.33)$ & 0.656 \\
\hline & 15 & rs17149458 & 6141866 & Intronic & $\mathrm{T}$ & A & 0.132 & 0.132 & $1.01(0.82 \sim 1.25)$ & 0.931 \\
\hline & 16 & rs10795791 & 6148346 & Upstream & $\mathrm{T}$ & $\mathrm{C}$ & 0.368 & 0.409 & $0.84(0.72 \sim 0.97)$ & $\underline{1.72 E-02}$ \\
\hline \multirow{4}{*}{$I L 2 R B$} & 1 & rs5995385 & 35849810 & Downstream & G & A & 0.295 & 0.303 & $0.95(0.81 \sim 1.11)$ & 0.491 \\
\hline & 2 & rs3218295 & 35863014 & Intronic & A & G & 0.174 & 0.173 & $1.02(0.84 \sim 1.22)$ & 0.878 \\
\hline & 3 & rs3218294 & 35863232 & Intronic & G & $\mathrm{C}$ & 0.202 & 0.205 & $0.98(0.82 \sim 1.17)$ & 0.800 \\
\hline & 4 & rs 2284033 & 35863980 & Intronic & G & A & 0.361 & 0.345 & $1.08(0.93 \sim 1.26)$ & 0.307 \\
\hline \multirow{2}{*}{$I L 2 R G$} & 1 & rs5981065 & 70208925 & Intronic & G & A & 0.353 & 0.350 & N/A & N/A \\
\hline & 2 & $\operatorname{rs} 17174152$ & 70319869 & Downstream & G & A & 0.101 & 0.093 & N/A & N/A \\
\hline
\end{tabular}

$P$-values $<0.05$ are indicated in bold. Abbreviations: A1, minor allele; A2, major allele; BP, base pair; $\mathrm{CI}$, confidence interval; MAF, minor allele frequency; OR, odds ratio; SNP, single nucleotide polymorphism; N/A, Not Applicable. The SNP positions are based on the NCBI Build 36 human genome assembly. 
Table 2. Results of the case-control association analysis between imputed SNP in the IL2RA gene on chromosome 10 and tuberculosis case in the KARE subjects (Result $P<0.05$ ).

\begin{tabular}{|c|c|c|c|c|c|c|c|c|c|}
\hline \multirow[b]{2}{*}{ No. } & \multirow[b]{2}{*}{ SNP } & \multirow[b]{2}{*}{$\mathrm{BP}$} & \multirow[b]{2}{*}{ Function } & \multirow[b]{2}{*}{ A1 } & \multirow[b]{2}{*}{ A2 } & \multicolumn{2}{|c|}{ MAF } & \multirow[b]{2}{*}{ OR $(95 \% \mathrm{CI})$} & \multirow{2}{*}{$\begin{array}{c}{ }^{*} \text { Additive } \\
P \text { value }\end{array}$} \\
\hline & & & & & & $\begin{array}{c}\text { Cases } \\
(\mathrm{n}=443)\end{array}$ & $\begin{array}{c}\text { Controls } \\
(\mathrm{n}=3,228)\end{array}$ & & \\
\hline I1 & rs764850 & 6048357 & Downstream & A & $\mathrm{G}$ & 0.212 & 0.177 & $1.28(1.07 \sim 1.53)$ & 6.92.E-03 \\
\hline $\mathrm{I} 2$ & rs 80006671 & 6048408 & Downstream & $\mathrm{T}$ & $\mathrm{C}$ & 0.212 & 0.177 & $1.28(1.07 \sim 1.53)$ & 6.92.E-03 \\
\hline $\mathrm{I} 3$ & rs59454145 & 6048914 & Downstream & $\mathrm{A}$ & G & 0.212 & 0.177 & $1.28(1.07 \sim 1.53)$ & 6.92.E-03 \\
\hline I4 & rs117040696 & 6050159 & Downstream & $\mathrm{T}$ & $\mathrm{C}$ & 0.212 & 0.177 & $1.28(1.07 \sim 1.53)$ & 6.92.E-03 \\
\hline I5 & rs138574189 & 6050267 & Downstream & $\mathrm{T}$ & A & 0.212 & 0.177 & $1.28(1.07 \sim 1.53)$ & 6.92.E-03 \\
\hline I6 & rs117632375 & 6050306 & Downstream & $\mathrm{G}$ & $\mathrm{C}$ & 0.212 & 0.177 & $1.28(1.07 \sim 1.53)$ & 6.92.E-03 \\
\hline I7 & rs12572257 & 6050630 & Downstream & A & G & 0.212 & 0.177 & $1.28(1.07 \sim 1.53)$ & 6.92.E-03 \\
\hline I8 & rs 12722610 & 6052172 & Downstream & G & A & 0.032 & 0.019 & $1.70(1.11 \sim 2.60)$ & 0.015 \\
\hline I9 & rs12722604 & 6053286 & Intronic & A & G & 0.254 & 0.317 & $0.73(0.62 \sim 0.86)$ & 1.53.E-04 \\
\hline $\mathrm{I} 10$ & rs 12722596 & 6056294 & Intronic & $\mathrm{C}$ & $\mathrm{T}$ & 0.032 & 0.018 & $1.76(1.15 \sim 2.70)$ & 9.88.E-03 \\
\hline I11 & rs11256342 & 6057231 & Intronic & G & $\mathrm{T}$ & 0.298 & 0.357 & $0.76(0.65 \sim 0.89)$ & 5.90.E-04 \\
\hline $\mathrm{I} 12$ & rs2386841 & 6057732 & Intronic & $\mathrm{T}$ & $\mathrm{G}$ & 0.490 & 0.436 & $1.25(1.08 \sim 1.44)$ & 2.71.E-03 \\
\hline $\mathrm{I} 13$ & rs 12572859 & 6058040 & Intronic & $\mathrm{C}$ & G & 0.164 & 0.139 & $1.23(1.01 \sim 1.49)$ & 0.038 \\
\hline I14 & rs 10752175 & 6061781 & Intronic & $\mathrm{T}$ & $\mathrm{C}$ & 0.245 & 0.214 & $1.21(1.03 \sim 1.44)$ & 0.023 \\
\hline $\mathrm{I} 15$ & rs6602368 & 6062915 & Intronic & $\mathrm{C}$ & $\mathrm{T}$ & 0.370 & 0.416 & $0.82(0.71 \sim 0.95)$ & 8.79.E-03 \\
\hline I16 & rs 12358961 & 6066195 & Intronic & A & $\mathrm{T}$ & 0.375 & 0.427 & $0.80(0.69 \sim 0.92)$ & 2.75.E-03 \\
\hline G1 & rs2025345 & 6067688 & Intronic & G & A & 0.376 & 0.428 & $0.80(0.69 \sim 0.93)$ & 2.87.E-03 \\
\hline I17 & rs 12572054 & 6069853 & Intronic & $\mathrm{C}$ & $\mathrm{T}$ & 0.281 & 0.338 & $0.76(0.65 \sim 0.89)$ & 7.63.E-04 \\
\hline I18 & rs 2025346 & 6070675 & Intronic & A & G & 0.279 & 0.336 & $0.76(0.65 \sim 0.89)$ & 6.35.E-04 \\
\hline I19 & rs2025347 & 6070831 & Intronic & G & A & 0.441 & 0.401 & $1.19(1.03 \sim 1.37)$ & 0.018 \\
\hline $\mathrm{I} 20$ & rs 10905641 & 6072293 & Intronic & $\mathrm{C}$ & A & 0.255 & 0.226 & $1.19(1.01 \sim 1.40)$ & 0.043 \\
\hline $\mathrm{I} 21$ & rs7068276 & 6073388 & Intronic & $\mathrm{G}$ & $\mathrm{T}$ & 0.435 & 0.397 & $1.17(1.02 \sim 1.36)$ & 0.028 \\
\hline $\mathrm{I} 22$ & rs12264061 & 6073487 & Intronic & G & A & 0.010 & 0.020 & $0.47(0.24 \sim 0.94)$ & 0.032 \\
\hline $\mathrm{I} 23$ & rs4747844 & 6074201 & Intronic & G & A & 0.440 & 0.404 & $1.17(1.01 \sim 1.35)$ & 0.034 \\
\hline $\mathrm{I} 24$ & rs7920946 & 6074634 & Intronic & $\mathrm{C}$ & $\mathrm{T}$ & 0.354 & 0.323 & $1.16(1.00 \sim 1.35)$ & 0.050 \\
\hline $\mathrm{I} 25$ & rs 12572136 & 6077191 & Intronic & G & $\mathrm{C}$ & 0.274 & 0.333 & $0.76(0.65 \sim 0.88)$ & 4.87.E-04 \\
\hline $\mathrm{I} 26$ & rs6602392 & 6078079 & Intronic & A & $\mathrm{C}$ & 0.274 & 0.333 & $0.76(0.65 \sim 0.88)$ & 4.87.E-04 \\
\hline $\mathrm{I} 27$ & rs 11256442 & 6079344 & Intronic & $\mathrm{T}$ & $\mathrm{C}$ & 0.470 & 0.427 & $1.20(1.04 \sim 1.38)$ & 0.013 \\
\hline $\mathrm{G} 2$ & rs7072398 & 6079846 & Intronic & A & G & 0.362 & 0.423 & $0.77(0.66 \sim 0.89)$ & 5.37.E-04 \\
\hline $\mathrm{I} 28$ & rs11256457 & 6080794 & Intronic & G & $\mathrm{C}$ & 0.357 & 0.409 & $0.79(0.68 \sim 0.92)$ & 2.39.E-03 \\
\hline I29 & rs 12722517 & 6081040 & Intronic & $\mathrm{C}$ & $\mathrm{T}$ & 0.357 & 0.323 & $1.18(1.01 \sim 1.36)$ & 0.033 \\
\hline $\mathrm{I} 30$ & rs791593 & 6083292 & Intronic & G & A & 0.358 & 0.324 & $1.18(1.02 \sim 1.36)$ & 0.031 \\
\hline G3 & rs4749926 & 6085312 & Intronic & $\mathrm{A}$ & G & 0.357 & 0.409 & $0.79(0.68 \sim 0.92)$ & 2.45.E-03 \\
\hline G4 & rs791587 & 6088699 & Intronic & A & G & 0.270 & 0.321 & $0.78(0.67 \sim 0.91)$ & 2.01.E-03 \\
\hline $\mathrm{I} 31$ & rs791588 & 6089342 & Intronic & G & $\mathrm{T}$ & 0.342 & 0.389 & $0.81(0.70 \sim 0.94)$ & 5.60.E-03 \\
\hline $\mathrm{I} 32$ & rs791589 & 6089571 & Intronic & G & A & 0.326 & 0.376 & $0.80(0.69 \sim 0.93)$ & 3.83.E-03 \\
\hline $\mathrm{I} 33$ & rs 1323658 & 6094354 & Intronic & $\mathrm{C}$ & A & 0.255 & 0.305 & $0.78(0.67 \sim 0.92)$ & 2.55.E-03 \\
\hline $\mathrm{I} 34$ & rs706778 & 6098949 & Intronic & $\mathrm{C}$ & $\mathrm{T}$ & 0.368 & 0.406 & $0.85(0.73 \sim 0.98)$ & 0.027 \\
\hline I35 & rs7072793 & 6106266 & Upstream & $\mathrm{T}$ & $\mathrm{C}$ & 0.369 & 0.409 & $0.84(0.73 \sim 0.97)$ & 0.020 \\
\hline $\mathrm{I} 36$ & rs7073236 & 6106552 & Upstream & $\mathrm{T}$ & $\mathrm{C}$ & 0.368 & 0.408 & $0.84(0.73 \sim 0.97)$ & 0.020 \\
\hline
\end{tabular}


Table 2. Results of the case-control association analysis between imputed SNP in the IL2RA gene on chromosome 10 and tuberculosis case in the KARE subjects (Result $P<0.05$ ) (Continued)

\begin{tabular}{|c|c|c|c|c|c|c|c|c|c|}
\hline \multirow[b]{2}{*}{ No. } & \multirow[b]{2}{*}{ SNP } & \multirow[b]{2}{*}{$\mathrm{BP}$} & \multirow[b]{2}{*}{ Function } & \multirow[b]{2}{*}{ A1 } & \multirow[b]{2}{*}{ A2 } & \multicolumn{2}{|c|}{ MAF } & \multirow[b]{2}{*}{ OR $(95 \% \mathrm{CI})$} & \multirow{2}{*}{$\begin{array}{c}{ }^{*} \text { Additive } \\
P \text { value }\end{array}$} \\
\hline & & & & & & $\begin{array}{c}\text { Cases } \\
(\mathrm{n}=443)\end{array}$ & $\begin{array}{c}\text { Controls } \\
(\mathrm{n}=3,228)\end{array}$ & & \\
\hline $\mathrm{I} 37$ & rs7096384 & 6106638 & Upstream & $\mathrm{C}$ & $\mathrm{T}$ & 0.368 & 0.408 & $0.84(0.73 \sim 0.97)$ & 0.020 \\
\hline G5 & rs10795791 & 6108340 & Upstream & A & $\mathrm{G}$ & 0.369 & 0.409 & $0.84(0.73 \sim 0.97)$ & 0.020 \\
\hline
\end{tabular}

*All data were selected with $P$-values $<0.05$. Abbreviations: $\mathrm{G}$ of no., genotyped number of SNP; I of no., imputed number of SNP; A1, minor allele; A2, major allele; BP, base pair; CI, confidence interval; MAF, minor allele frequency; OR, odds ratio; SNP, single nucleotide polymorphism. The SNP positions are based on the NCBI Build 37 human genome assembly.

Table 3. Results of the Regulome DB of imputed SNP in the IL2RA gene on chromosome 10

\begin{tabular}{lcccccccc}
\hline \hline \multirow{2}{*}{ SNP } & \multirow{2}{*}{ BP } & A1 & A2 & & & & \multicolumn{2}{c}{ Regulome DB } \\
\cline { 5 - 8 } & & & & Score & TFBS & DNase & Proteins bound & Motifs \\
\hline rs764850 & 6048357 & A & G & $3 \mathrm{a}$ & + & + & GTAT1, POLR2A & ZNF740, NERF1a \\
rs12722596 & 6056294 & C & T & $2 \mathrm{a}$ & + & + & CTCF, RAD21, SMC3 & RFX, BRCA1:USF2 \\
rs10752175 & 6061781 & C & T & $2 \mathrm{~b}$ & + & + & E2F6 & PPARG::RXRA \\
rs1323658 & 6094354 & C & A & $3 \mathrm{a}$ & + & + & SPI1, CHD1, IKZF1 & HNF4, Esrra \\
\hline
\end{tabular}

Abbreviations: SNP, single nucleotide polymorphism; BP, base pair; A1, minor allele; A2, major allele; TFBS, transcription binding factor site; +, affect. The SNP positions are based on the NCBI Build 37 human genome assembly.

고 이 중 rs10795791은 5' 방향의 upstream 영역에서 나타 났다.

\section{IL2RA 유전자 SNP의 Linkage disequilibrium (LD) 구조}

$I L 2 R A$ 유전자에서 확인한 유의성이 높은 6 개의 SNP 간 의 연관 불균형 현상이 나타나는지 Haploview 프로그램을 활용하여 확인해 보고자 하였다. 상대적 위험도가 낮았던 5 개의 $\mathrm{SNP}$ 중 $5 \mathrm{~kb}$ 확장 지역에 존재하는 $\mathrm{SNP}$ 을 제외한 4 개의 SNP는 하나의 LD block을 형성하고 있었다. 다른 LD block에는 상대적 위험도가 높은 SNP이 포함되어 있 었다(Fig. 1)

\section{IL2RA 유전자 SNP imputation 후 상관성 분석 결과}

$\mathrm{KARE}$ 유전형 자료를 기반으로 하여 IL2RA 유전자 $\mathrm{SNP}$ imputation을 수행하여 더 많은 SNP과 결핵과의 상관 성 여부를 확인해 보았다. 그 결과 182 개의 $\mathrm{SNP}$ 이 확인되 었고 그 중 42개의 SNP이 통계적으로 유의하였다. Imputation 수행 전 분석 결과는 결핵 발병과 상대적 위험도가 낮은 SNP이 대부분이었던 반면 imputation 수행 후에는 상대적 위험도가 높은 $\mathrm{SNP}$ 의 수와 낮은 $\mathrm{SNP}$ 의 수가 비 슷하게 나타났다. Imputation 수행 후 결핵 발생과 유의한
상관관계를 보이는 $\mathrm{SNP}$ 들의 수가 증가한 것은 $I L 2 R A$ 유 전자의 유전적 다형성이 결핵 발병에 영향을 줄 가능성이 높다는 것을 의미한다(Table 2).

\section{IL2RA 유전자의 SNP이 유전자와 단백질 발현에 미치 는 영향}

Imputation 후 유의성이 높은 IL $2 R A$ 유전자가 어떻게 유 전자 혹은 단백질 발현에서 영향을 미칠 것인지 RegulomeDB (http://www.regulomedb.org/index)에서 확인해 보았다. 확인 결과 rs12722596, rs10752175, rs764850, rs1323658의 4개의 SNP에서 의미 있는 score를 확인할 수 있었다. 그 중 rs12722596는 전사 인자 결합 반응에 영향을 줄 수 있 을 뿐만 아니라 DNase peak 차이가 있다는 것을 확인할 수 있었다. 뿐만 아니라 이곳은 본래 $\mathrm{RFX}$ 와 BRCA1: $\mathrm{USF} 2$ 의 motif로 작용하기 때문에 IL2RA 유전자 발현에 영 향을 줄 수 있다는 것을 확인할 수 있었다. 또한 rs764850 는 IL $2 R A$ 유전자의 $3^{\prime}$ 말단 쪽 $5 \mathrm{~kb}$ 확장 범위에 존재하는 $\mathrm{SNP}$ 임에도 불구하고 통계적 유의성과 높은 RegulomeDB score가 의미 있게 나타난 것은 유전자에 인접한 지역이 유전적 다양성의 조절에 있어서 중요한 역할을 할 가능성 이 있음을 보여준다(Table 3). 


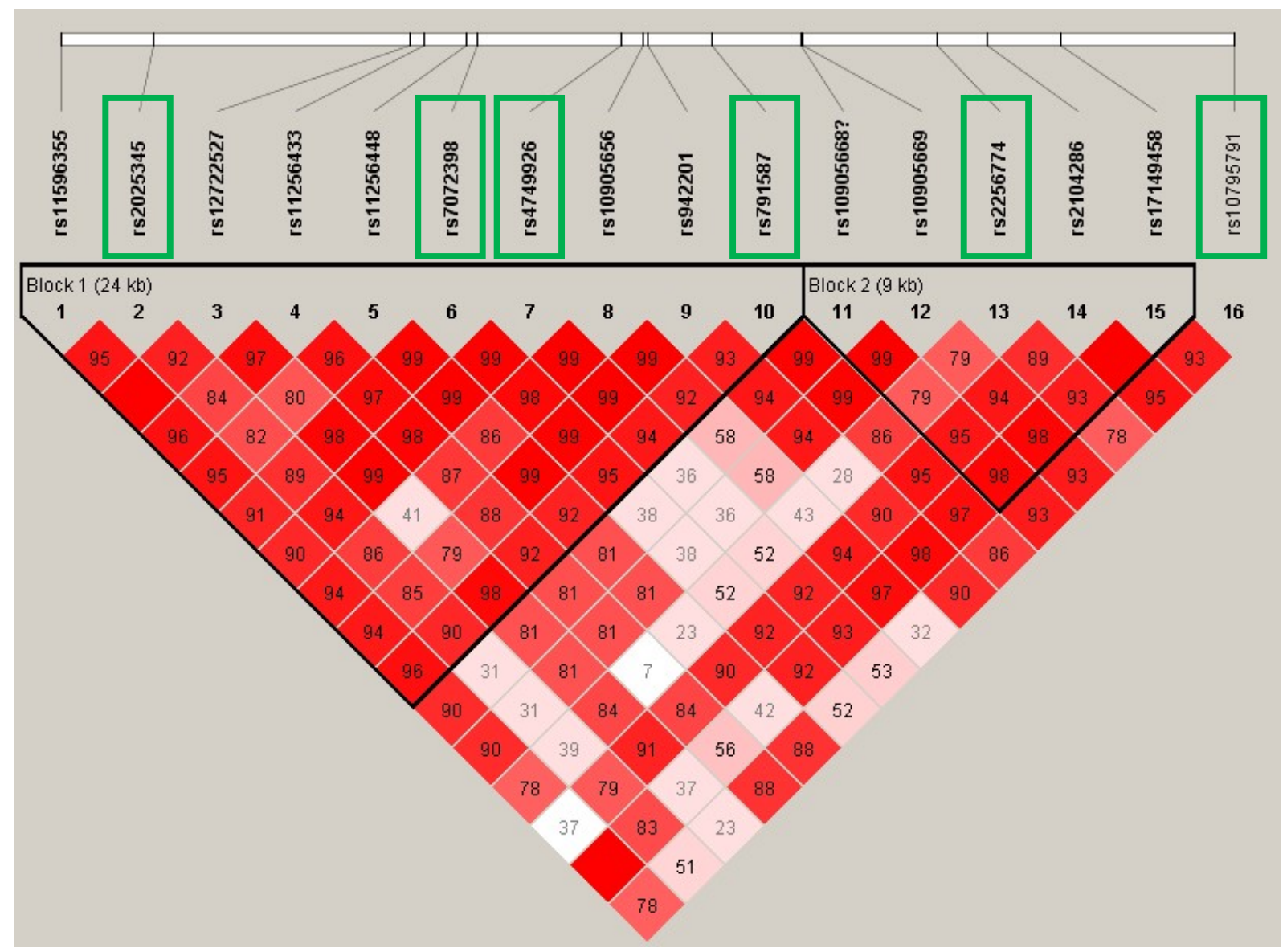

Fig. 1. Linkage disequilibrium of IL2R A SNP on chromosome 10. The 16 SNPs and LD structure were shown by a Haploview of LD $\left(r^{2}\right)$ based on genotyping data from 8,842 KARE subjects and are generated by using the Haploview program. Of the 6 SNPs with significance, 4 SNPs belong to Block 1, and 2 SNPs belong to Block 2. Since there are significant differences in different blocks, it is expected that each SNP will affect the outbreak of tuberculosis.

\section{고 찰}

본 연구에서는 IL-2 receptor를 발현하는 유전자에서 $\mathrm{SNP}$ 의 결핵 환자군과 건강 대조군간 $\mathrm{MAF}$ 차이에 따른 통계적 유의성을 분석하여 유전적 변이에 따른 결핵 발 병과의 상관성에 대하여 알아보고자 하였다. 그 결과 $I L 2 R B$ 와 $I L 2 R G$ 는 결핵 환자군과 건강 대조군간 유전 변이 의 MAF 차이가 일정 수준 이하로 나타났다. 이것은 IL-2 receptor $\beta$ 와 $\gamma$ chain 유전자의 유전 변이가 결핵 발병과 상 관성이 낮다는 것으로 생각할 수 있었다. 그러나 IL $2 R A$ 유전자는 6 개의 SNP에서 결핵 발병과 높은 유의성이 확 인되었다. 이 $\mathrm{SNP}$ 중 $\mathrm{MAF}$ 가 건강 대조군에 비하여 결핵 환자군에서 낮은 $\mathrm{SNP}$ 과 높은 $\mathrm{SNP}$ 모두 확인할 수 있었
다. 이것은 IL2RA 유전자의 유전 변이는 결핵 발병에 있 어서 다양한 방향으로 영향을 미칠 수 있다는 것을 의미 한다. 또한 위의 SNP의 $\mathrm{LD}$ 구조를 확인해 보았을 때 상 대적 위험도의 방향성이 반대인 두 $\mathrm{SNP}$ 이 서로 다른 $\mathrm{LD}$ block에 속해 있는 것을 확인할 수 있었으며 같은 방향성 을 갖는 $\mathrm{SNP}$ 은 같은 $\mathrm{LD}$ blcok에 속해 있는 것을 볼 수 있었다(Fig. 1). 위의 결과들을 통하여 IL-2 receptor를 발현 하는 유전자 중 $\alpha$ chain을 발현하는 유전자에 존재하는 $\mathrm{SNP}$ 들이 결핵 발병과 통계적으로 유의한 상관성이 있다 는 것을 확인할 수 있었다.

기존의 KARE 자료에서 imputation 후의 SNP을 기준으 로 IL $2 R A$ 유전자의 통계적 유의성을 분석해 보았을 때 기 존의 결과보다 많은 SNP을 선별할 수 있었으며 높은 유 의성을 갖는 $\mathrm{SNP}$ 도 확인할 수 있었다. 또한 RegulomeDB 
결과가 높은 score를 갖는 것도 확인할 수 있었다. 결국 imputation 후의 결과는 IL $2 R A$ 유전자의 유전 변이가 어 떻게 결핵 발병에 영향을 주는지 자세하게 확인해 볼 수 있었고 유전 변이와 결핵 발병의 상관성이 있다는 사실을 뒷받침 해주었다.

인체 면역에 관여하는 여러 유전자의 유전적 차이는 면역체계를 이루는 요소들의 차이를 만들어 결국 결핵균 의 인체 침입과 이에 대한 방어와 관련된 감수성 변화 를 가져올 수 있다. 결핵균에 대한 면역학적 관점에서 보 게 되면 결핵균이 감염되었을 때 인체 내에서는 다양한 면역반응이 일어나며 이에 관여하는 세포들은 다양하다 (Kleinnijenhuis et al., 2011; Dey and Bishai, 2014). 결핵 감염 초기에 결핵균이 완전하게 제거되지 않으면 $\mathrm{T}$ cell이 결핵 균에 대한 면역에 관여하게 된다. T cell은 결핵균을 포함 한 육아종을 형성하여 그 안에서 균의 사멸을 유도한다 (Gideon et al., 2015). 하지만 환자의 면역학적 상태에 따라 결핵균의 사멸은 조절되며 이 환자의 상태는 환자에 감염 된 결핵균의 특성 뿐만 아니라 환자의 임상증상과 면역 력 등이 관여한다. T cell과 macrophage는 결핵균을 사멸 하고 병변을 형성한다. 이 때 CD4+ T cell은 IL-2, IFN- $\gamma$ 와 같은 cytokine을 분비하여 항원 발현을 증강시키고 세 포 매개 면역반응을 촉진시키는 역할을 한다(Edwards and Kirkpatrick, 1986). 또한 활성화된 T cell은 IL-2 receptor가 세포 표면에 발현되어 IL-2와 결합한다(Morgan et al., 1976; Rubin et al., 1985). 결합된 IL-2는 휴지기 T cell을 effector $\mathrm{T}$ cell, memory $\mathrm{T}$ cell로 분화하도록 촉진하고 Thl cytokine 의 발현 조절에 관여한다. T cell의 표면에 발현하는 IL-2 receptor 중 $\alpha$ chain은 soluble한 상태(sIL-2R $\alpha$ )로 유리되어 남게 된다. 앞선 연구에서는 정상인의 혈청에 존재하는 sIL-2R $\alpha$ 보다 세포 매개 면역반응이 진행될 때의 sIL-2R $\alpha$ 가 증가한 것을 관찰하였다(Rubin et al., 1985). sIL-2R $\alpha$ 의 정상 혈청 농도보다 증가한 상태는 $\mathrm{T}$ cell의 활성화 정도 와 세포 면역 기능의 증감을 예측할 수 있는 지표로 활용 되는 연구는 활발하게 진행되고 있다. 따라서 $\mathrm{IL}-2 \mathrm{R} \alpha$ 를 발현하는 유전자에 유전적 변이가 생긴다면 IL-2Ra가 발 현되는 양에 조절이 생길 것이고 그렇게 되면 $\mathrm{IL}-2 \mathrm{R} \alpha$ 가 관여하는 면역체계에는 변화가 있을 것이다. 결국 결핵균 의 특성과 환자의 임상증상이 결핵의 감수성과 관련하여 중요하지만 면역에 관련된 유전적 다형성 또한 결핵에 대 한 감수성에 영향을 줄 수 있다.

그동안 국내의 많은 연구에서 결핵의 발병과 관련하여 결핵균의 특성을 고려하는 연구들이 진행되어 왔다(Oh et al., 2009; Park et al., 2012; Cho et al., 2014). 그러나 본 연구에 서는 결핵 발병에 영향을 줄 수 있는 면역에 관여하는 숙 주의 유전적 다형성이 결핵 발병과 관한 환자의 감수성이 조절될 수 있는 가능성을 제시해 주고 있으며 이 결과를 통하여 결핵에 유전적인 감수성이 있는 환자에 대한 연구 와 관리가 가능할 것이라고 생각한다.

\section{ACKNOWLEDGEMENTS}

This research was supported by Basic Science Research Program through the National Research Foundation of Korea (NRF), funded by Ministry of Sciences, ICT \& Future Planning (2017R1C1B5016589). Epidemiologic data used in this study were from the Korean Genome and Epidemiology Study (KoGES) of the Korea Centers for Disease Control \& Prevention, Republic of Korea.

\section{CONFLICT OF INTEREST}

The authors have no conflicts of interest to disclose.

\section{REFERENCES}

Caccamo N, Guggino G, Joosten SA, Gelsomino G, Di Carlo P, Titone L, Galati D, Bocchino M, Matarese A, Salerno A, Sanduzzi A, Franken WP, Ottenhoff TH, Dieli F. Multifunctional CD4(+) T cells correlate with active Mycobacterium tuberculosis infection. Eur J Immunol. 2010. 40: 2211-2220.

Casey R, Blumenkrantz D, Millington K, Montamat-Sicotte D, Kon OM, Wickremasinghe M, Bremang S, Magtoto M, Sridhar S, Connell D, Lalvani A. Enumeration of functional T-cell subsets by fluorescence-immunospot defines signatures of pathogen burden in tuberculosis. PLoS One. 2010. 5: e15619.

Cho JE, Cho SN, Cho S. RpoB ${ }_{127-135}$ Peptide Derived from Mycobacterium tuberculosis is Processed and Presented to HLAA*0201 Restricted CD8+ T Cells via an Alternate HLA-I Processing Pathway. 2014. 20: 250-255.

Cho YS, Go MJ, Kim YJ, Heo JY, Oh JH, Ban HJ, Yoon D, Lee MH, Kim DJ, Park M, Cha SH, Kim JW, Han BG, Min H, Ahn Y, Park MS, Han HR, Jang HY, Cho EY, Lee JE, Cho NH, Shin C, Park T, Park JW, Lee JK, Cardon L, Clarke G, McCarthy MI, Lee JY, Lee JK, Oh B, Kim HL. A large-scale genome-wide association study of Asian populations uncovers genetic factors influencing eight quantitative traits. Nat Genet. 2009. 41: 527-534. 
Comstock GW. Tuberculosis in twins: a re-analysis of the Prophit survey. Am Rev Respir Dis. 1978. 117: 621-624.

Corbett EL, Watt CJ, Walker N, Maher D, Williams BG, Raviglione $\mathrm{MC}$, Dye $\mathrm{C}$. The growing burden of tuberculosis: global trends and interactions with the HIV epidemic. Arch Intern Med. 2003. 163: 1009-1021.

Dey B, Bishai WR. Crosstalk between Mycobacterium tuberculosis and the host cell. Semin Immunol. 2014. 26: 486-496.

Edwards D, Kirkpatrick CH. The immunology of mycobacterial diseases. Am Rev Respir Dis. 1986. 134: 1062-1071.

Gaffen SL, Liu KD. Overview of interleukin-2 function, production and clinical applications. Cytokine. 2004. 28: 109-123.

Gideon HP, Phuah J, Myers AJ, Bryson BD, Rodgers MA, Coleman MT, Maiello P, Rutledge T, Marino S, Fortune SM, Kirschner DE, Lin PL, Flynn JL. Variability in tuberculosis granuloma $\mathrm{T}$ cell responses exists, but a balance of pro- and antiinflammatory cytokines is associated with sterilization. PLoS Pathog. 2015. 11: e1004603.

International HapMap Consortium. The International HapMap Project. Nature. 2003. 426: 789-796.

Jin HS, Park S. Association of the CD226 Genetic Polymorphisms with Risk of Tuberculosis. Biomedical Science Letters. 2017. 23: 89-95.

Kaufmann SH. How can immunology contribute to the control of tuberculosis?. Nat Rev Immunol. 2001. 1: 20-30.

Kleinnijenhuis J, Oosting M, Joosten LA, Netea MG, Van Crevel $\mathrm{R}$. Innate immune recognition of Mycobacterium tuberculosis. Clin Dev Immunol. 2011. 2011: 405310.

Li Y, Willer CJ, Ding J, Scheet P, Abecasis GR. MaCH: using sequence and genotype data to estimate haplotypes and unobserved genotypes. Genet Epidemiol. 2010. 34: 816-834.

Liao W, Lin JX, Leonard WJ. IL-2 family cytokines: new insights into the complex roles of IL-2 as a broad regulator of T helper cell differentiation. Curr Opin Immunol. 2011. 23: 598-604.
Morgan DA, Ruscetti FW, Gallo R. Selective in vitro growth of T lymphocytes from normal human bone marrows. Science. 1976. 193: 1007-1008.

Oh SY, Kim HB, Shin MS, Kim JW, Park SH. Pyrosequencing Based Detection of Rifampicin or Isoniazid Resistant in Mycobacterium tuberculosis. Korean J Clin Lab Sci. 2009. 41: 24 -30 .

Park S, Cho JE, Kim YS, Cho SN, Lee H. Bfl-1/A1 Molecules are Induced in Mycobacterium Infected THP-1 Cells in the Early Time Points. J Exp Biomed Sci. 2012. 18: 201-209.

Rubin LA, Kurman CC, Fritz ME, Biddison WE, Boutin B, Yarchoan R, Nelson DL. Soluble interleukin 2 receptors are released from activated human lymphoid cells in vitro. J Immunol. 1985. 135: 3172-3177.

Sester U, Fousse M, Dirks J, Mack U, Prasse A, Singh M, Lalvani A, Sester M. Whole-blood flow-cytometric analysis of antigenspecific CD4 T-cell cytokine profiles distinguishes active tuberculosis from non-active states. PLoS One. 2011. 6: e17813.

Sharma S, Kalia NP, Suden P, Chauhan PS, Kumar M, Ram AB, Khajuria A, Bani S, Khan IA. Protective efficacy of piperine against Mycobacterium tuberculosis. Tuberculosis (Edinb). 2014. 94: 389-396.

Wang S, Diao N, Lu C, Wu J, Gao Y, Chen J, Zhou Z, Huang H, Shao L, Jin J, Weng X, Zhang Y, Zhang W. Evaluation of the diagnostic potential of IP-10 and IL-2 as biomarkers for the diagnosis of active and latent tuberculosis in a BCG-vaccinated population. PLoS One. 2012. 7: e51338.

https://doi.org/10.15616/BSL.2018.24.2.94

Cite this article as: Lee SI, Jin HS, Park S. Association of Genetic Polymorphism of IL-2 Receptor Subunit and Tuberculosis Case. Biomedical Science Letters. 2018. 24: $94-101$ 